Volume 1

3-1-2018

\title{
The Trillion-Dollar Question
}

Follow this and additional works at: https://via.library.depaul.edu/depaul-magazine

Part of the Behavioral Economics Commons

\section{Recommended Citation}

(2018) "The Trillion-Dollar Question," DePaul Magazine: Vol. 1: Iss. 412021, Article 6.

Available at: https://via.library.depaul.edu/depaul-magazine/vol1/iss412021/6

This Article is brought to you for free and open access by the Alumni Publications at Digital Commons@DePaul. It has been accepted for inclusion in DePaul Magazine by an authorized editor of Digital Commons@DePaul. For more information, please contact digitalservices@depaul.edu. 


\section{THE}
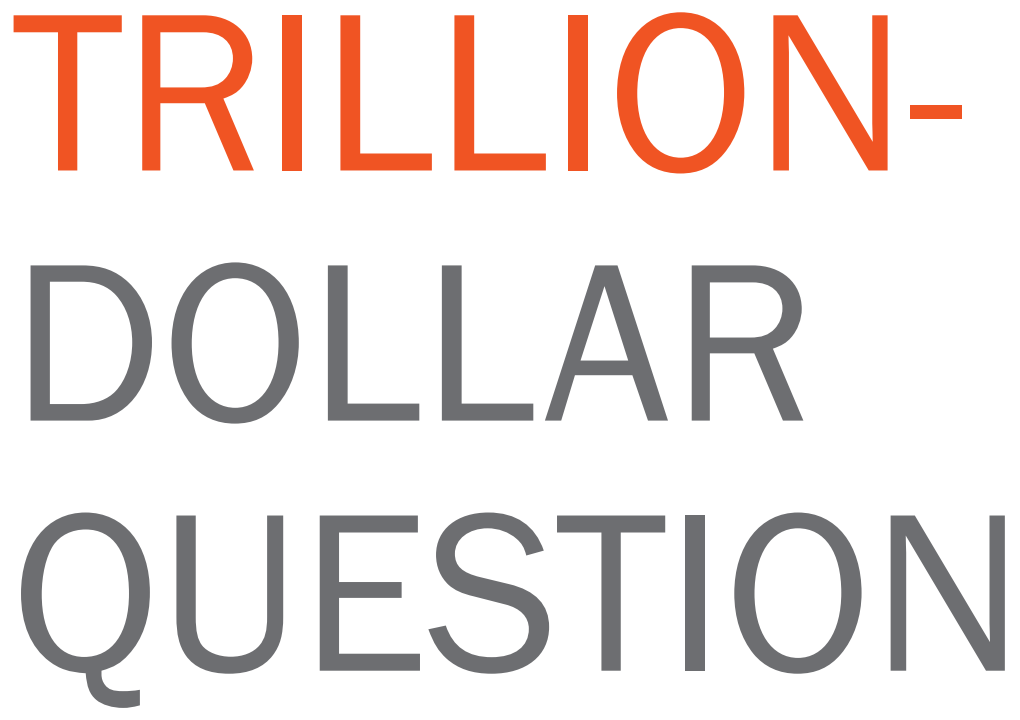

\section{Carolyn Leonard (BUS '64) and Monika Black (CSH PhD '12) are on a mission to help the financial services industry better understand and serve female investors.}

\section{By Marilyn Ferdinand \\ Photos by Tom Evans}

W hen Carolyn Leonard and Monika Black first started meeting with executives at financial institutions to discuss how they work with their investor clientele, the women were told, "We know our clients." When they asked, "What about cracking the code on finance and women?" the confusing response was "We know nothing about women."

"Women are going to control $\$ 22$ trillion of investable assets by 2020 . We are going to inherit, by 2050 , something like $\$ 35$ trillion," says Leonard. "We are the market!"

That market is the reason Leonard launched DyMynd, her "boutique financial empowerment firm," in 2012, with Black serving as her chief strategy officer. Both women are passionate about helping women investors get the service and consideration they deserve from the advisors who handle their money, as well as better understand their own relationship with money, a task more emotionally fraught than many realize.

\section{NECESSITY, MEET INVENTION}

In 1976, Leonard had to face her relationship with money head on-she needed one! After earning her business degree from DePaul and teaching briefly, she spent more than a decade as a stay-at-home wife and mother, only to have her marriage end in divorce. She found herself wondering how she was going to pay her husband for his half of the marriage property and continue to provide a comfortable life for herself and her children. "I said, 'Well, sweetheart, we're going to need to take that business degree and do something," Leonard recalls.

Prior to her divorce, Leonard had started an indoor plant business with her friend Marsha Serlin. "Neither of us had a background in horticulture, but we decided that if we like plants, we could learn on the job," Leonard says. The women also found the advice of informal mentors invaluable. "The men in the greenhouse were very happy to help us - PhDs who nobody ever asked questions. We were just sponges, and they were happy to tell us everything they knew about plants and trees." 


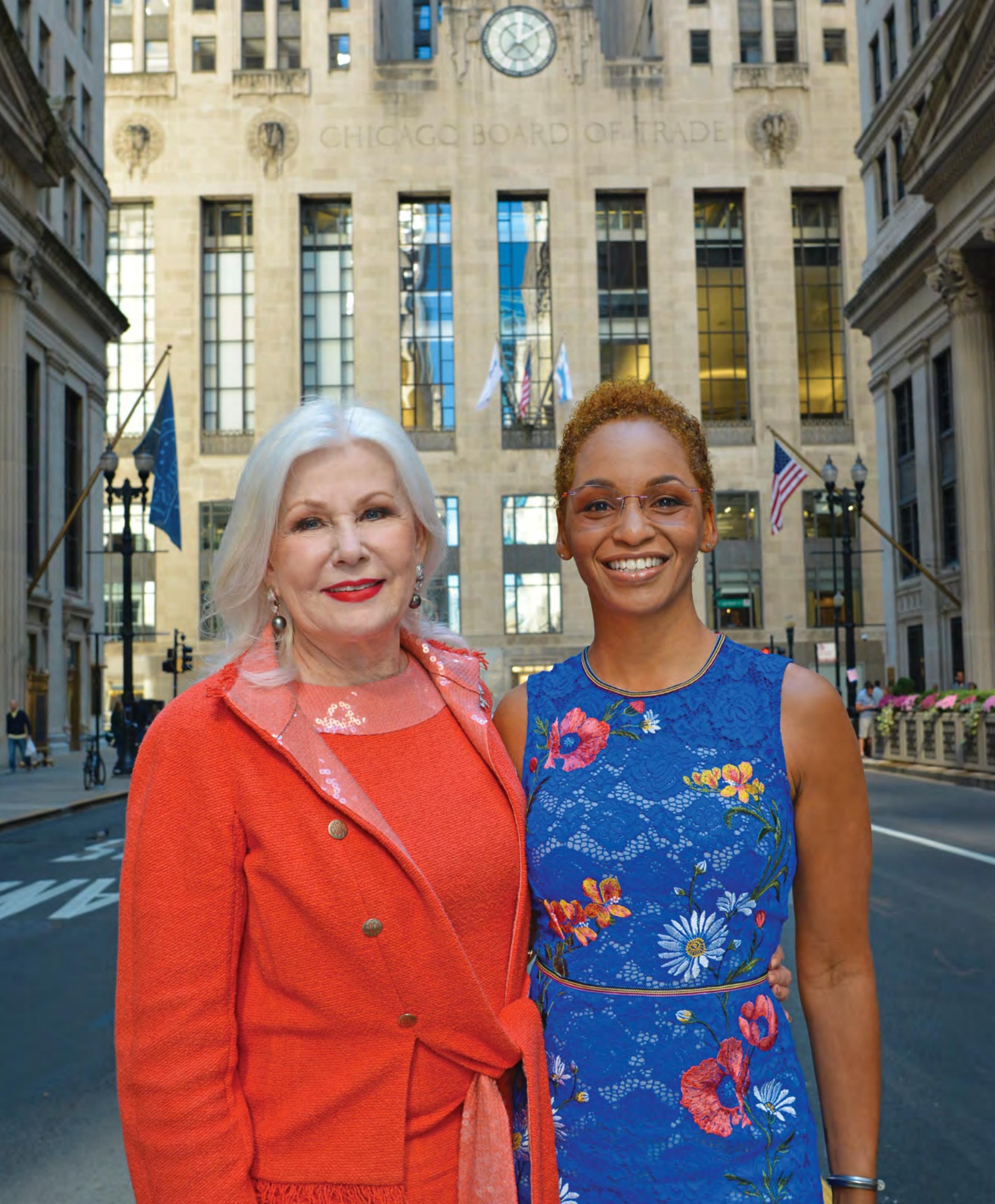




\section{“IF YOU REALLY WANT TO HELP WOMEN OVERCOME BARRIERS, YOU'VE GOT TO HELP THEM ECONOMICALLY."}

\author{
-Monika Black (CSH PhD '12)
}

Although the business was stable, it wasn't providing Leonard with the kind of income she needed. It was time to restrategize. Many of her clients were members of the Chicago Mercantile Exchange, and Leonard had traders for neighbors. Observation led Leonard to a life-changing conclusion. "It was obvious that there was a dirty secret in Chicago - that anyone could trade," Leonard says. "The big commodity traders at that time weren't college graduates, or very few were." Hoping to increase her earnings substantially, Leonard left the plant business to learn how to trade stock options. (Serlin founded and is now CEO of United Scrap in Cicero, Ill.)

Leonard was moving into largely uncharted territory for women. "I learned to trade at a time when there was no book. You learned by doing, and because no one would hire a woman at that time for that career, I had to put myself in business," she says. The price was high. To finish paying off her husband and buy her seat at the Chicago Board Options Exchange (CBOE), Leonard had to raise $\$ 250,000$ - the equivalent of almost $\$ 1.1$ million today. Leonard's mother, a stock investor herself and a strong supporter of her daughter's ambitions, cosigned the note for her seat and loaned her money to get started.

Just as she had done with the plant business, Leonard sought out a mentor to help her learn the ropes. "He happened to be a PDD in math who came to Chicago to teach," Leonard says, but he gave up teaching when he made his fortune as a trader. "I found him and sought him out as a mentor because I knew that, number one, he was very successful, so he knew how to trade, and number two, he was a professor, so I suspected he knew how to teach.” He was very helpful in coaching her on the basics of options trading.

Other men were not so helpful. "When I started to trade in the pit, men told me they wouldn't trade with me because I was a woman, and worked against me by saying to other men, 'We don't trade with her," Leonard remembers.

Leonard's moment of truth came six months after she started trading on the floor. A 25 percent move in $3 \mathrm{M}$ stock and nothing but buy orders meant Leonard had to start selling, even though she was short about 150,000 shares of 3M stock. "At the time I was selling all those options, I was nauseous. I did it because I knew I was never going to get another chance-either you stand up there and take your lumps, or you're gone. At the end of the week, I had a six-figure trading account, and I had earned the respect of all the guys."

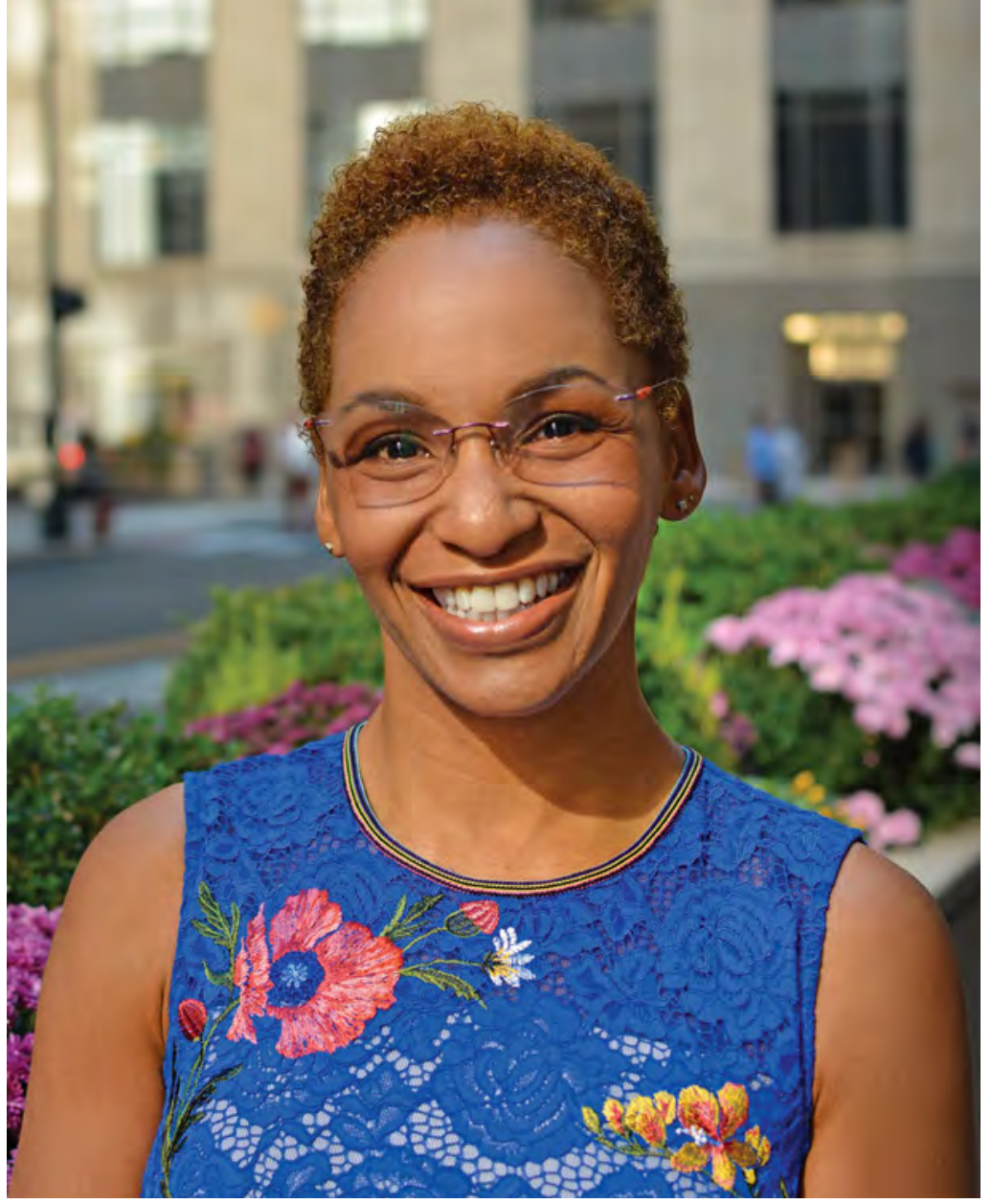

Thus, “Carolyn Jean the Option Queen” was born. She spent 21 years building a formidable reputation as one of the first independent female market makers at the CBOE.

\section{LOOKING FOR A FIT}

Monika Black faced her own challenges growing up in the Columbus, Ohio, suburb of Upper Arlington with her parents and older brother. "The real story with my family that impacted my life greatly was that my grandparents were deaf," Black says. "I don't recognize myself as growing up in English-speaking culture. All my communication styles came from deaf culture-you say what you say to the person when they're there. The formalities of hearing people took me a long time to figure out."

Although Black may have been socially awkward in some ways as a result of her immersion in deaf culture, she gained advantages that have served her well in her current role at DyMynd. "I get the 'metadata' of what people say, I feel all of that," she says. "Women have very social and normative ways of relating to money. I can see those 'aha' moments that people have."

Her background as an African American in a predominantly white suburb also had an impact. "It was certainly worse for my parents at the time," she says. The family moved to the suburbs in 1969 because Black's mother believed that the goal of the civil rights movement was to be equal. "She doesn't understand the word 'no,"” Black laughs. "But because they were in survival mode as well as trying to hold onto black culture, they ended up being quite lonely."

Black found her niche in athletics. "My parents put me in gymnastics at a very young age, and I ended up being a high jumper because I could just do really high back tucks." She was recruited for the University of Michigan track and field team and earned All-American status four times. 
Her energy, discipline and competitiveness drove Black to pursue her education. While she was earning the second of her two master's degrees from The Ohio State University, she participated in an American Hospital Association summer enrichment program and then a one-year internship at Chicago's Northwestern Memorial Hospital. "I got invested in the Chicago community," she says, and stayed. She also met and married Tomer Yogev, a business strategist.

Her education journey, however, was not over. "I was driving by DePaul, and the voice inside of me literally said, 'You will go there one day." She earned her PhD in community psychology in 2012 from DePaul's College of Science and Health, where she now serves as an instructor and adjunct professor of psychology.

\section{BEYOND THE NUMBER}

Leonard hung up her iconic pink trading jacket in 1997 and worked in real estate until the stock market tanked in 2008. Her panicked female friends came to her for advice, and a light bulb went off in her head. She contacted Yogev to develop a business focused on women and finance and eventually brought Black, who helped create the model for DyMynd, into the business.

Leonard and Black say that money is the final frontier for women, no matter how much money they have. "If you really want to help women overcome barriers, you've got to help them economically," says Black. "We're calling for a mind shift." That shift needs to happen not only within women, but also in the financial planning industry.

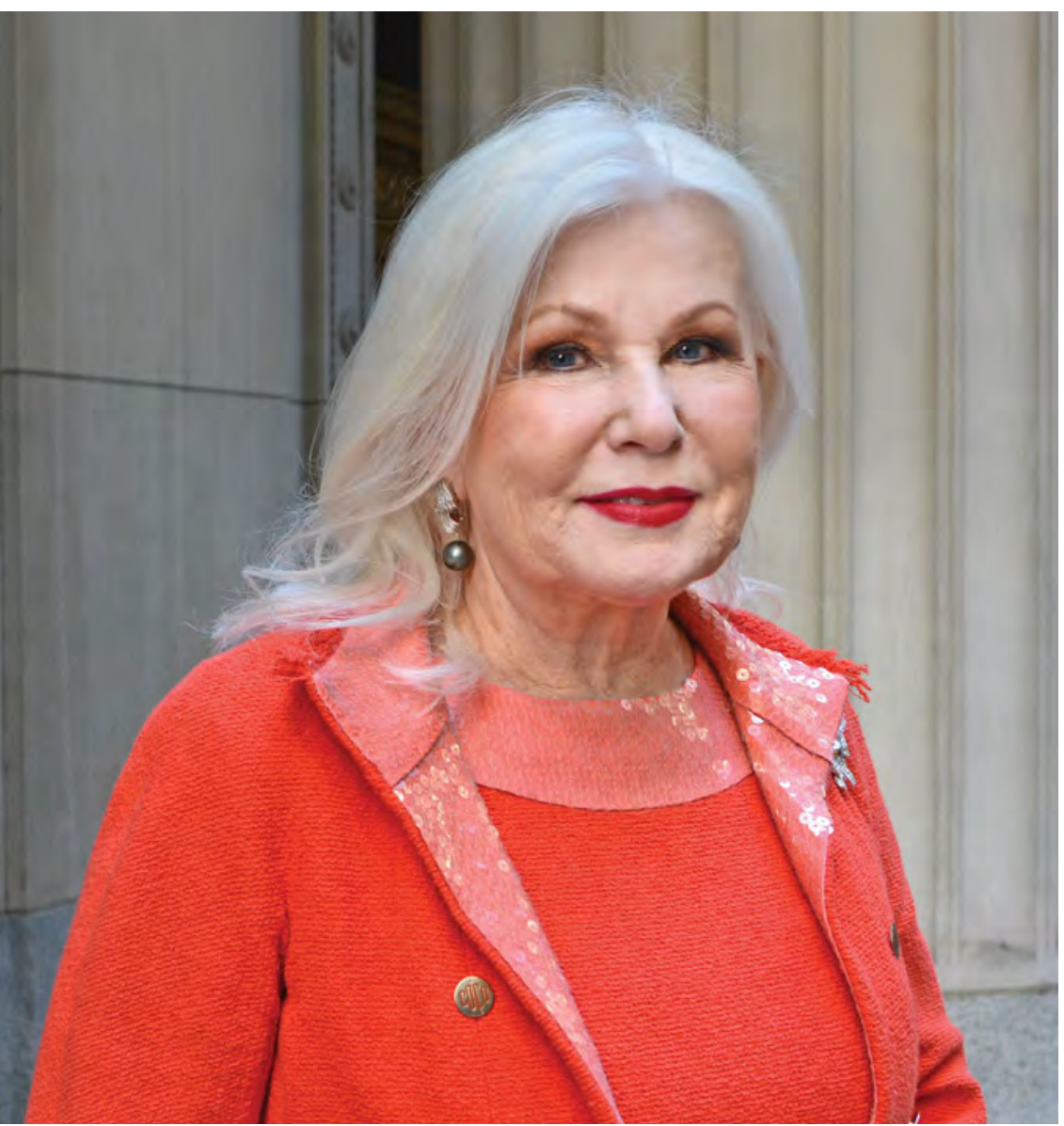

\section{"WOMEN ARE GOING TO CONTROL \$22 TRILLION OF INVESTABLE ASSETS BY 2020. WE ARE THE MARKET."}

-Carolyn Leonard (BUS '64)

"The industry has set up a financial plan to get you to a number," says Leonard. "What we've heard, from women's perspective, is that money is more than a number to them: It's a means to an end."

Black says women have an entire ecosystem of care for which they feel responsible. She illustrates this point by recalling a roundtable discussion she and Leonard held for women, called Money and Merlot. They are not against having a financial plan, but they question plans that target a number as the measure of success.

"We had a female bank CEO in the room. She says, 'We put together a financial plan for every woman. What are you saying?'

"I said, 'It's the wrong number.'

"She said, 'How do you mean?'

"We said, 'She's not tracking toward a number that is just about her and her family unit. She's tracking toward impact, which can be influenced by her care networks or how many people she feels emotionally and financially responsible for, but also that inner bag lady who feels like she may outlive her money one day. You have to factor in the size of the care network and the bag lady effect, and in between those two is where she's home. Then you build the model for that person."”

At the core of success for women and the financial advisors with whom they work is a trusting partnership. "Three years ago, what we were hearing was 'My concern is regulatory compliance,"” says Leonard. "My thing was, well, if financial advisors build up a trusting relationship, compliance isn't an issue because through the conversation, you're going to get the right result." Slowly, the industry is changing the terms of engagement with their female clients.

\section{MAPPING THE FUTURE}

Reflecting on her alma mater, Black says, "DePaul, especially the psychology program and community psychology, was very much a coming home for me. No organization is perfect, but I'd never seen one where the mission was so carried throughout. I really valued that, because it gave me a little more freedom to be my authentic self. People are still in struggle. I want to help people out of struggle."

Leonard says, "Being in business school, most of the time I was the only woman in a class. I think it just set me up throughout my life to understand that I might always be going into areas where I was the outlier. At the same time, I would love to see more women going into business and the business school. It affords women the opportunity to take better care of their families, and we know that when women succeed, the whole family succeeds." 